\title{
Analytical Quality in Environmental Studies: Uncertainty Evaluation of Chemical Concentrations Determined by INAA
}

\author{
Elvis Joacir de França ${ }^{1 *}$, Elisabete A. De Nadai Fernandes ${ }^{1}$, Márcio Arruda Bacchi ${ }^{1}$ and \\ Mitiko Saiki ${ }^{2}$ \\ ${ }^{1}$ Centro de Energia Nuclear na Agricultura; Universidade de São Paulo; Av. Centenário 303; 13416-000; \\ ejfranca@cena.usp.br; Piracicaba - SP - Brasil. ${ }^{2}$ Instituto de Pesquisas Energéticas e Nucleares; Comissão \\ Nacional de Energia Nuclear; Travessa R, 400; 05508-900; São Paulo - SP - Brasil
}

\begin{abstract}
Instrumental neutron activation analysis (INAA) is a measurement technique of high metrological level for the determination of chemical elements. In the context of BIOTA/FAPESP Program, leaves of trees have been evaluated by INAA for biomonitoring purposes of the Atlantic Forest. To assure the comparability of results in environmental studies, a leaf sample of Marlierea tomentosa (Myrtaceae family) showing the lowest concentrations of chemical elements was selected for the evaluation of analytical quality of the determination under unfavorable conditions. Nevertheless, the homogeneity of chemical concentrations of sample at the $95 \%$ of confidence level has been achieved and INAA has presented repeatability of $2 \%$ for the determination of $\mathrm{Br}, \mathrm{Co}, \mathrm{Cs}, \mathrm{Fe}, \mathrm{K}, \mathrm{Na}, \mathrm{Rb}$ and $\mathrm{Sr}$, the uncertainty could have been overestimated. For the evaluation of uncertainty due to the variability of chemical concentrations in the sample, Jackknife and Bootstrap methods were used to estimate the maximum expected percent standard deviation. The uncertainty budget was considered adequate for the reporting chemical concentrations of environmental samples determined by INAA.
\end{abstract}

Key words: Uncertainty, INAA, Jackknife, Bootstrap

\section{INTRODUCTION}

Instrumental neutron activation analysis (INAA) is a measurement technique of high metrological quality, in principle as a primary ratio method for determination of chemical concentration (mass fraction), benefiting the comparability of the results (Bode et al., 2000; Bacchi et al., 2000). The sources that contribute to uncertainty are well known in INAA owing to the fact that it is easy to express the uncertainty of chemical concentration determined by INAA (Bode et al., 2000). Uncertainty is defined as "a parameter associated with the results of a measurement, that characterizes the dispersion of the values that could reasonably be attributed to the chemical concentration" (Kucera et al., 2000). In fact, the uncertainty calculation should take into account the variability of the data as well as the intrinsic characteristics of the analysis process like weighting, counting statistics, neutron flux monitoring and geometry (Kucera et al., 2000). Multielementar analytical techniques performed within the metrology concepts are important tools for the evaluation of natural ecosystems, providing the complete characterization of compartments in

\footnotetext{
${ }^{*}$ Author for correspondence
} 
terms of chemical composition (França et al., 2005; França et al., 2004a).

The establishment of environmental standards for environmental impact study is one of the main goals of the BIOTA (Virtual Institute for the Sustainable Use of Biodiversity of the São Paulo State) of the Fundação de Amparo à Pesquisa do Estado de São Paulo (FAPESP). In this context, several projects have been developed, including the project "Diversity, Dynamics and Conservation in São Paulo State Forests: 40 ha of Permanent Plots", which aims at the environmental characterization of long-term plots (10 ha) of the conservation units of great relevance. The Parque Estadual Carlos Botelho (PECB) has lush vegetation being one of the most important ecosystems for biodiversity conservation in the world (Myers et al., 2000).

For the identification of possible anthropogenic impacts, one of the BIOTA's researches is being developed for the biomonitoring of chemical elements in the long-term plot of the PECB (França et al., 2005; França et al., 2004). Biomonitoring has been done through the determination of chemical elements in leaves of the most abundant trees by INAA.

Table 1 - Element concentrations $\left(\mathrm{mg} \mathrm{kg}^{-1}\right)$, standard deviation (STD\%), uncertainty (u\%) and repeatability (repeat.\%) obtained in leaf samples of Marlierea tomentosa

\begin{tabular}{|c|c|c|c|c|}
\hline Replicate & $\mathbf{B r}$ & Co & Cs & $\mathbf{F e}$ \\
\hline 1 & 8.40 & 0.497 & 0.163 & 74.7 \\
\hline 2 & 8.39 & 0.506 & 0.156 & 74.8 \\
\hline 3 & 8.66 & 0.505 & 0.166 & 73.9 \\
\hline 4 & 8.52 & 0.495 & 0.161 & 73.0 \\
\hline 5 & 8.57 & 0.502 & 0.161 & 74.9 \\
\hline 6 & 8.57 & 0.505 & 0.167 & 74.2 \\
\hline 7 & 8.42 & 0.496 & 0.159 & 76.3 \\
\hline 8 & 8.70 & 0.507 & 0.163 & 74.0 \\
\hline 9 & 8.48 & 0.500 & 0.163 & 73.7 \\
\hline 10 & 8.46 & 0.504 & 0.162 & 78.7 \\
\hline Mean & 8.52 & 0.502 & 0.162 & 74.8 \\
\hline$S T D \%$ & 1.3 & 0.9 & 1.9 & 2.2 \\
\hline$u \%$ & 2.4 & 0.7 & 3.3 & 1.5 \\
\hline Repeat. \% & 1.3 & 0.9 & 1.9 & 2.2 \\
\hline Replicate & $\mathrm{K}$ & $\mathrm{Na}$ & $\mathrm{Rb}$ & $\mathrm{Sr}$ \\
\hline 1 & 8660 & 336 & 28.4 & 62.4 \\
\hline 2 & 8390 & 332 & 28.1 & 62.9 \\
\hline 3 & 8540 & 343 & 28.4 & 63.7 \\
\hline 4 & 8510 & 336 & 28.1 & 61.0 \\
\hline 5 & 8670 & 338 & 28.4 & 59.9 \\
\hline 6 & 8740 & 342 & 29.5 & 64.0 \\
\hline 7 & 8550 & 340 & 28.7 & 62.1 \\
\hline 8 & 8880 & 347 & 28.7 & 62.7 \\
\hline 9 & 8590 & 341 & 28.5 & 62.8 \\
\hline 10 & 8590 & 335 & 28.2 & 61.8 \\
\hline Mean & 8610 & 339 & 28.5 & 62.3 \\
\hline$S T D \%$ & 1.6 & 1.3 & 1.4 & 1.9 \\
\hline$u \%$ & 1.7 & 2.2 & 2.6 & 3.1 \\
\hline Repeat. \% & 1.6 & 1.3 & 1.4 & 1.9 \\
\hline
\end{tabular}




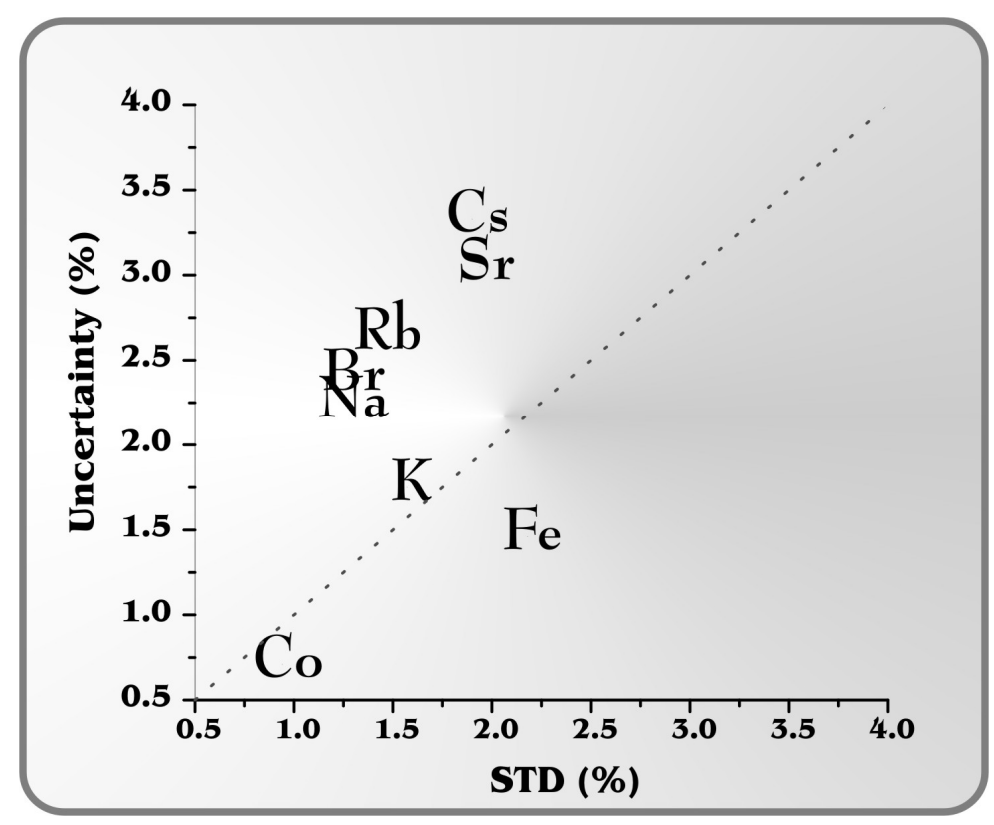

Figure 1 - Scatter plot of individual mean uncertainties and percent standard deviations

Considering the importance of producing reliable results for the establishment of environmental standards and the difficulties of increasing the number of sample replicates, a study for assessment of the homogeneity and the repeatability of the determination of chemical elements by INAA of leaves of Marlierea tomentosa (Myrtaceae family) was previously designed. This species showed the lowest concentrations and, therefore, was selected for evaluation and analysis under unfavorable condition (França et al., 2004b). Although homogeneity of chemical concentrations at the 95\% confidence level has been found in sample and the technique has presented repeatability of $2 \%$ for $\mathrm{Br}, \mathrm{Co}, \mathrm{Cs}, \mathrm{Fe}, \mathrm{K}, \mathrm{Na}, \mathrm{Rb}$ and $\mathrm{Sr}$, the uncertainty could have been overestimated (França et al., 2004b). Statistical approach involving Jackknife and Bootstrap methods was then developed to estimate the maximum expected percent standard deviation for the evaluation of the uncertainty budget at Laboratório de Radioisótopos of the Centro de Energia Nuclear na Agricultura.

\section{EXPERIMENTAL}

Results of ten test portions analyzed by INAA were used in the study (Table 1). Details of the analysis and the presented results can be found elsewhere (França et al., 2004b).

The uncertainties were calculated by the Quantu software (Bacchi et al., 2003) and compared to the standard deviation observed (Fig. 1). It can be verified that the uncertainty is about 20 to $50 \%$ higher than the observed standard deviations (STD\%) for $\mathrm{Br}, \mathrm{Cs}, \mathrm{Na}, \mathrm{Rb}$ and $\mathrm{Sr}$.

This fact corroborates the study of estimating maximum standard deviation by Jackknife (1), Bootstrap (2) and Jackknife-Bootstrap (3) methods (Mainly, 2001) considering this variable as the main source for uncertainty calculation. These methods were selected for calculating confidence intervals in situations where no better methods are easily used (Mainly, 2001). Tests for the confidence limits were performed to verify the reasonability of these intervals in including the uncertainty and observed standard deviation. For Bootstrap, the method used was the bias corrected percentile confidence limits (Mainly, 2001). About 1000 samples were generated using Resampling Stats for Excel.

\section{RESULTS AND DISCUSSION}

The confidence limits using the methods Jackknife (1), Bootstrap (2) and BootstrapJackknife (3) can be seen in Table 2. In Fig. 2, it is 
possible to confirm that the uncertainty was within the limits established. The highest values for standard deviation were obtained when applying Jackknife and Bootstrap-Jackknife methods, while the Bootstrap confidence limits, even corrected by bias, did not include the uncertainty for all elements except for $\mathrm{Co}, \mathrm{Fe}$ and $\mathrm{K}$. Therefore, the uncertainty budget could be considered adequate mainly by agreeing to the maximum expected standard deviation of chemical concentrations. It is interesting to examine the $\mathrm{Fe}$ results in Fig. 2, since all statistical methods have indicated that both uncertainty and standard deviation would be expected to be higher (from 1.5 to $5.5 \%$ in the case of Jackknife method) likely due to normality problems of the dataset.
To check the consistency of the confidence limits, the observed standard deviation and uncertainty were compared to the confidence limits estimated by all methods (Table 3). Of course, for all elements the observed standard deviation is within the confidence limits proposed by JackknifeBootstrap technique while the uncertainty was included in about 95\% of the 1000 bootstrap samples for $\mathrm{Co}, \mathrm{Fe}$ and $\mathrm{K}$. The problematic of estimating confidence limits using Bootstrap and Jackknife has been discussed elsewhere (Mainly, 2001).

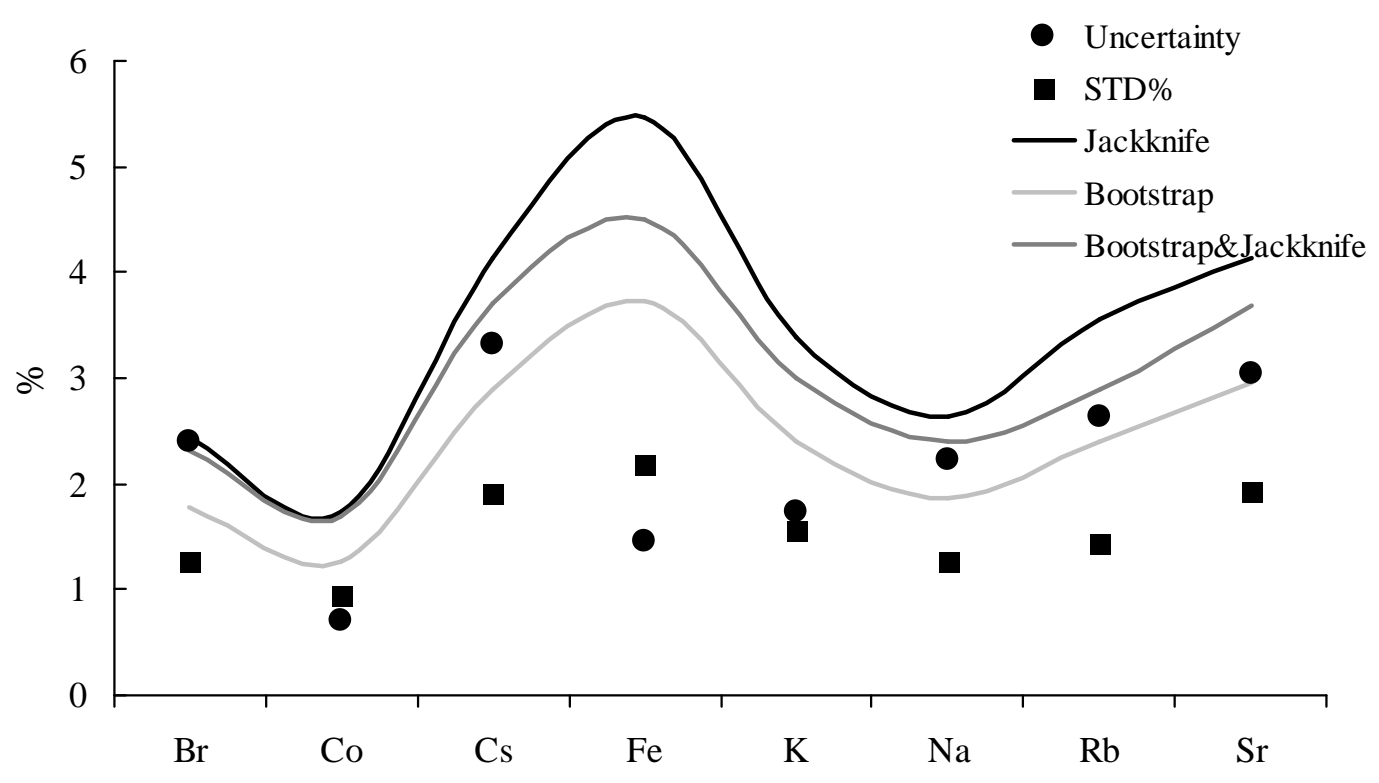

Figure 2 - Standard deviation, uncertainty and confidence limits obtained using Jackknife, Bootstrap and Jackknife-Bootstrap methods 
Table 2 - Uncertainty (u\%), observed standard deviation (STD\%) and confidence limits (in \%) for standard deviation at the $95 \%$ confidence level

\begin{tabular}{ccccccc}
\hline Element & u\% & STD\% & \multicolumn{3}{c}{ Jackknife } \\
(1)
\end{tabular}

Table 3 - Percent frequency of uncertainty and observed standard deviation lower than the superior limit established by Jackknife-Bootstrap methods

\begin{tabular}{ccc}
\hline Element & Uncertainty & Observed STD \\
\hline $\mathrm{Br}$ & 49 & 99 \\
$\mathrm{Co}$ & 100 & 100 \\
$\mathrm{Cs}$ & 67 & 97 \\
$\mathrm{Fe}$ & 97 & 90 \\
$\mathrm{~K}$ & 94 & 97 \\
$\mathrm{Na}$ & 64 & 98 \\
$\mathrm{Rb}$ & 66 & 91 \\
$\mathrm{Sr}$ & 76 & 98 \\
\hline
\end{tabular}

\section{CONCLUSIONS}

Bootstrap and Jackknife methods allowed us to estimate the maximum expected standard deviations that were comparable to the uncertainty provided by the Quantu software at the LRI/CENA/USP analytical conditions for determination of chemical elements in environmental samples.

\section{ACKNOWLEDGEMENTS}

The authors are thankful to the Fundação de Amparo à Pesquisa do Estado de São Paulo (FAPESP) for the financial support.

\section{RESUMO}

A análise por ativação neutrônica instrumental (INAA) é uma técnica analítica de alto nível metrológico para a determinação de elementos químicos. No contexto do programa BIOTA/FAPESP, folhas de árvores vêm sendo avaliadas empregando-se INAA para a biomonitoração da Mata Atlântica. Para garantir a comparabilidade dos resultados em estudos ambientais, amostra de folhas de Marlierea tomentosa, cujas concentrações de elementos químicos obtidas foram as menores, foi selecionada para a avaliação da qualidade analítica na mais desfavorável situação. Esta avaliação levou em consideração a homogeneidade das concentrações de elementos e a estimativa da 
repetitividade analítica. Embora a homogeneidade das concentrações tenha sido detectada em nível de $95 \%$ de confiança e a INAA tenha apresentado repetitividade estimada em $2 \%$ para $\mathrm{Br}, \mathrm{Co}, \mathrm{Cs}$, $\mathrm{Fe}, \mathrm{K}, \mathrm{Na}, \mathrm{Rb}$ e $\mathrm{Sr}$, a incerteza pode ter sido superestimada. Para a avaliação da incerteza devido à variabilidade das concentrações químicas na amostra, os métodos Jackknife e Bootstrap foram empregados para estimar o desvio padrão máximo esperado. A estimativa de incerteza foi considerada adequada para a geração de resultados de concentrações químicas em estudos ambientais.

\section{REFERENCES}

Bacchi, M. A. and Fernandes, E. A. N. (2003), Quantu design and development of a software package dedicated to $\mathrm{k}_{0}$-standardized INAA. Journal of Radioanalytical and Nuclear Chemistry, 257 : (2), 577-582.

Bacchi, M. A.; Fernandes, E. A. N. and Oliveira, H. (2000), A Brazilian experience on $\mathrm{k}_{0}$ standardized neutron activation analysis. Journal of Radioanalytical and Nuclear Chemistry, 245 : (1), 217-222.

Bode P.; Fernandes, E. A. N. and Greenberg, R. R. (2000), Metrology for chemical measurements and the position of INAA. Journal of Radioanalytical and Nuclear Chemistry, 245 : (1), 109-114.

França, E. J.; De Nadai Fernandes, E. A.; Bacchi, M. A.; Rodrigues, R. R. and Verburg, T. G. (2005), Biodiversity conservation in the Atlantic Forest: inorganic chemical investigation of native trees. Environmental Monitoring and Assessment, 102, 349-357.

França, E. J.; De Nadai Fernandes, E. A.; Bacchi, M. A. and Saiki M. (2004b), Qualidade analítica da determinação de elementos químicos por ativação neutrônica instrumental em amostras ambientais. In: Congresso Latino-Americano de Metrologia: A Metrologia e a Competitividade no Mercado Globalizado, 4., Foz do Iguaçu. Artigos. Foz do Iguaçu: METROSUL.
França, E. J.; De Nadai Fernandes, E. A.; Bacchi, M. A. and Saiki, M. (2004a), Native trees as biomonitors of chemical elements in the biodiversity conservation of the Atlantic Forest. Journal of Atmospheric Chemistry, 49, 579-592.

Kucera, J.; Bode, P. and Stepanek, V. (2000), The 1993 ISO Guide to the expression of uncertainty in measurement applied to NAA. Journal of Radioanalytical and Nuclear Chemistry, 245 : (1), 115-122.

Mainly, B. F. J. (2001), Randomization, bootstrap and Monte Carlo methods in Biology. New Zeland: Chapman \& Hall/CRC. pp.34-67.

Myers, N.; Mittermeier, R. A.; Mittermeier, C. G.; Da Fonseca, C. A. B. and Kent J. (2000), Biodiversity hotspots for conservation priorities. Nature, 403, 853-858.

Received: July 29, 2005; Revised: September 05, 2005; Accepted: November 22, 2005. 